\title{
GREEK PRE-SERVICE PHYSICAL EDUCATION TEACHERS' BELIEFS ABOUT CURRICULAR ORIENTATIONS: INSTRUMENT VALIDATION AND EXAMINATION OF FOUR IMPORTANT GOALS
}

\author{
Manolis Adamakis*, Katerina Zounhia, Dimitris Hatziharistos, Maria Psychountaki
}

Faculty of Physical Education and Sport Science, National and Kapodistrian University of Athens, Athens, Greece

Submitted in December, 2013

BACKGROUND: The way people interpret reality is influenced by their mental constructions, their cognitive abilities and their beliefs. Physical Education (PE) students have a wide range of formed beliefs concerning the purposes of PE, which cannot be easily modified, even during undergraduate studies.

OBJECTIVE: This study validated the scores from a previously constructed questionnaire and investigated the Physical Education students' belief systems toward the Greek curricular outcome goals.

METHODS: Students $(N=483$; males $=259$, females $=224)$ from a Greek Faculty of Physical Education and Sport Science shared their beliefs about curricular outcomes. They completed the Greek version of the four factor instrument "Attitudes/beliefs toward curriculum in physical education". A confirmatory factor analysis was conducted for the validation of the instrument and MANOVAs followed in order to control for group differences. Finally, a profile analysis was run in order to determine if PE students considered each goal to be equally important.

RESULTS: The validation of the instrument confirmed the proposed four factors dependant model. Both internal consistency and the confirmatory factor analysis fit indices produced valid and reliable scores. The profile analysis was significant, indicating that students did not view the outcome goals as equally important. The leading goal was physical activity and fitness, followed by self-actualization, social development and motor skill development. MANOVA results for comparisons between sub-groups revealed significant differences only between genders.

CONCLUSIONS: Between groups similarities and differences are discussed, focusing on the classification of the four important outcome goals. Currently, Greek Physical Education students consider physical activity and fitness outcome goal as the most important, while motor skill development is considered the least important one.

Keywords: Students, fitness, health, self-actualization, motor skill, social development, questionnaire, validity, reliability, CFA.

\section{INTRODUCTION}

The way people interpret reality is influenced by their mental constructions, their cognitive abilities and their beliefs. A person's beliefs, attitudes and values form his/her belief system. The process of defining beliefs has caused much confusion and a universally accepted and clear definition does not exist, since "beliefs" constitute a very flexible term (Pajares, 1992). According to Goldin (2002) beliefs can be defined as "multiplyencoded, internal cognitive/affective configurations, to which the holder attributes truth value of some kind" (p. 59). Furthermore, beliefs can be regarded as social-

\footnotetext{
* Address for correspondence: Manolis Adamakis, Faculty of Physical Education and Sport Science, National and Kapodistrian University of Athens, 41 Ethnikis Antistasis street, 17237 Dafne, Athens, Greece. E-mail: manosadam@phed.uoa.gr
}

ly constructed representational systems that people use to interpret and act upon the world (Rust, 1994).

Many surveys have been carried out regarding teachers' beliefs in different subject matters, such as mathematics, history and physics. Teachers in other content areas, such as music, Physical Education (PE) etc., often have much flexibility within national and state standards, in order to select activities and sequencing. They can rely on their personal belief systems to achieve the desired outcomes when designing the national curriculum's implementation. Furthermore, teachers' beliefs systems guide their behaviors, decisions, actions and attitudes toward students, as well as their teaching effectiveness and strategies (Lara-Cinisomo, Fuligni, Ritchie, Howes, \& Karoly, 2008). So it is of great importance to understand what PE teachers believe about important curricular outcome goals, and especially the physical activity and fitness goal which is the prevailing one worldwide (Kulinna \& Silverman, 1999). 


\section{The Greek PE curriculum}

According to the Greek curriculum (Ministry of Education and Religious Affairs [M.E.R.A.], 2003), the general aim of PE in elementary and secondary education is to contribute primarily to pupils' physical development, to help their spiritual and mental growth and their harmonious integration into society. This definition is based upon Kirk's (1993) approach. He has identified three key domains of students' personalities: (a) psychokinetic, (b) emotional and (c) cognitive, which need to be developed through PE. Of these areas, PE in Greece primarily addresses to the psychokinetic domain, then the emotional and finally the cognitive domain (M.E.R.A., 2003). Priority is given to motor skill development and sport participation, and through this, the development of their natural abilities and the improvement of health. About $60 \%$ of the lesson plans in the curriculum's handbook are based on this approach.

Physical activity participation and the promotion of health is the internationally dominant goal (Pate et al., 2006; Welk \& Meredith, 2008). Physical activity has the potential to contribute effectively to the morphological, cardio-respiratory, metabolic, motor and muscular fitness of children (Welk, Eisenmann, \& Dollman, 2006). This goal is considered the most important these days, due to the symptoms of a degenerative way of living in modern western societies, and especially since childhood overweight rates have increased significantly lately, both at a national and a global level (Roditis, Parlapani, Tzotzas, Hassapidou, \& Krassa, 2009; Tambalis et al., 2009). Furthermore, it helps in the creation of a socially acceptable body image, because obese persons are not socially acceptable and are often criticized for their external appearance (Colquhoun, 1990). So schools are considered attractive settings in which to promote positive health behaviors because students spend large amounts of time in the school environment and elements of the aforementioned Greek PE curriculum are directly related to health (Pate et al., 2006). Due to these critical issues, the main curricular goal in the Greece (motor skill development) receives significant criticism (Hatziharistos, 2003; Zounhia, 2000).

On the other hand, the criticism of this physical activity goal is that many people think there is a linear correlation between physical activity, fitness and health (Tinning, 1990). This is not scientifically precise and their relationship is far from being unproblematic (Burrows, Wright, \& Jungersen-Smith, 2002). According to Tinning (2010), this functions on the "energy intake and energy consumption" approach and fails to take into consideration the dialectical relationship between the individual and the society. It simply reduces the complex causes of diseases into simple factors related to individuals' behavior. In order to overcome this inconsistency, people should be educated toward these problematic discourses (Adamakis, Stavrou, Georgiadis, \& Yannakoulia, 2014; Tining, 2010) and wider social and environmental changes are needed in order to achieve appropriate health levels through physical activity participation (Welk et al., 2006).

\section{Previous research on PE students' beliefs}

Teaching in PE could probably be a simpler task if all PE teachers agreed on a number of specific goals students should achieve. This would mean that there would be a general consensus on the desired outcomes. Of course, in order for this consensus to be achieved, in every school there should be the same time of practice, equipment, facilities and state funding (Ennis, 1996). However, this is not possible. As long as beliefs depend on the social context and are related to certain circumstances which have created them, it is not surprising that different belief systems exist among PE teachers, which are often contradictory (Ennis, 1994).

According to the international literature, beliefs are developed in three phases: (a) when individuals are still studying in school, (b) from personal life experiences and (c) during their university studies (Nash, 2003; Tsangaridou, 2006). The first two represent the acculturation phase and the third one the professional socialization. There is, however, a fourth phase, the organizational socialization, during which teachers enter the actual work setting, they teach in schools and learn the values and skills needed in order to organize their work. It is possible that the latter phase runs counter to the previous three (Zounhia, 2009).

The first two phases (schooling and personal experiences) seem to be the most important for the formation of teaching beliefs. This happens because students' and teachers' beliefs have been developed and are already very strong before their entrance into the university (Curtner-Smith, Hastie, \& Kinchin, 2008; Matanin \& Collier, 2003; Nash, 2003). More specifically, PE students have a wide range of shaped beliefs about the desirable outcomes of PE, which cannot be modified or changed easily, even during the professional preparation programs (Curtner-Smith, 1999; Doolittle, Dodds, \& Placek, 1993; Placek et al., 1995). In particular, the "core" beliefs, which are the most powerful and ingrained ones, are formed early in childhood, and affect directly or indirectly other beliefs. In order for an undergraduate curriculum to modify deeply held beliefs, it must satisfy the wider range of students' needs and should have clear and consistent thematic bases. Furthermore, the appropriate people and professors should exist to serve as powerful role models and promote certain beliefs (Graber, 1995, 1996). Field experi- 
ences are also influential filters for changing students' beliefs (Tsangaridou, 2008).

With regard to the desired curricular outcome goals, the majority of studies have shown that PE teachers and students believe that all outcome goals are important (Guan, McBride, \& Xiang, 2005; Kulinna, Brusseau, Ferry, \& Cothran, 2010; Kulinna \& Silverman, 2000; Tsangaridou, 2008; Wang \& Koh, 2006). Some studies have concluded that the primary outcome goal is motor skill development (Placek et al., 1995; Xiang, Lowy, \& McBride, 2002) and this is more obvious in the elementary education setting (Matanin \& Kollier, 2003). Others have found that physical activity and fitness that leads to the health enhancement are the most important PE outcomes (Kulinna et al., 2010; Matanin \& Kollier, 2003; Wang \& Koh, 2006). Placek et al. (1995) and Matanin and Kollier (2003) assumed that these two goals can be achieved by playing team sports. The self-actualization goal is considered an important one, especially in eastern countries (Guan et al., 2005; Wang \& Koh 2006; Xiang et al., 2002), because societal trends in these countries emphasize a harmonious development of the whole human's personality. Gender differences in these beliefs systems, in general, do not exist (Guan et al., 2005; Kulinna \& Silverman, 2000; Placek et al., 1995). However, Alshammari (2004) found that in his social context significant differences existed between men and women, which can be related to the nature of the PE culture in Kuwait and people's needs.

In Greece, till now, no study has been done in order to find out what undergraduate PE students believe about the curricular outcome goals. Internationally, these studies are very limited, and often with contradictory results. So we consider it of major importance to validate an instrument in order to map this field and try, in the future, to understand how these beliefs are created and how they can be modified.

\section{Research questions}

1. Is the "Beliefs toward curricular outcomes" a valid and reliable instrument for measuring students' beliefs in Greece?

2. How are the four important PE outcome goals classified by the Greek PE students?

3. Are there any differences between those beliefs between students of different gender, the type of sport they are practicing and faculty characteristics'?

\footnotetext{
1 In Greece, in order for someone to study in the University, he/she has to succeed in the National University admission exams. According to their results, they have the right to choose the faculty of their preference. However, it is a common issue that their results are below expectations and they do not enter their primary choice faculty, so they have to settle for another faculty.
}

\section{METHODOLOGY}

\section{Instrumentation}

The instrument we used was designed to measure PE teachers' belief systems related to four important outcomes. The original instrument (Kulinna \& Silverman, 1999) contains 36 items, nine of each of four domains representing important outcomes for school PE programs: (a) physical activity and fitness, (b) self-actualization, (c) motor skill development and (d) social development. The instrument used a five-point Likerttype scale, with $1=$ extremely important to $5=$ not important. In the most recent research (Kulinna et al., 2010), data were reverse coded, so $1=$ extremely important became a 5 so that higher scores reflected higher values. The latter method of reverse coded scoring was used in our research. It had been previously validated three times, twice in the U.S.A. (Kulinna \& Silverman, 1999; Kulinna et al., 2010) and once in China (Guan et al., 2005), with satisfactory results.

\section{Greek preliminary study of instrument validation}

Adamakis, Zounhia, Hatziharistos, and Psychountaki (2012) conducted a preliminary validation study. Five PE experts translated the questionnaire and a final translation was created. All experts were professors in a Faculty of PE and Sport Science. The expert validation form developed was submitted to six sport pedagogy and psychology experts to determine the content validity of the instrument. They selected the most appropriate domain group for each single item. The mean percentage of agreement of the experts on all items was .96. Similarly, there was strong agreement between the experts on the four domains, with all measurements greater than .92. Due to this high percentage of agreement, no modifications were made by the experts on the proposed questionnaire.

The translated questionnaire was administered to $41 \mathrm{PE}$ students (men $n=23$, women $n=18$ ), aged $20.68 \pm 1.51$ years, in order to control the translation quality and whether the items were comprehensible to them. The result showed that the questionnaire was very comprehensible $(>.90)$, there were no misinterpretations and it was easy to complete. Finally another $72 \mathrm{PE}$ students (men $n=37$, women $n=35$ ), aged $22.2 \pm 2.57$ years, took part in the test-retest reliability (Pearson $r$ and intraclass correlation coefficients) and internal consistency (Cronbach's $\alpha$ ) analysis. The results are presented in Table 1.

\section{Recruitment}

The participants in the present study were 483 undergraduate students, $21.88 \pm 3.57$ years, from the Faculty of PE and Sport Science of the University of Athens, Greece, representing all four years of university studies. Random stratified clustered sampling was the sampling 
Table 1

Cronbach's $\alpha$ and Pearson r indices of the Belief Systems Instrument (Adamakis, Zounhia, Hatziharistos, \& Psychountaki, 2012)

\begin{tabular}{lccc}
\hline & Cronbach $\alpha$ & Pearson $r$ & $\begin{array}{c}\text { Intraclass correlation } \\
\text { coefficients }\end{array}$ \\
\hline Overall beliefs system & .94 & $.89 * *$ & .93 \\
Physical activity and fitness & .83 & $.82 * *$ & .90 \\
Self-actualization & .84 & $.84 * *$ & .92 \\
Motor skill development & .85 & $.82 * *$ & .90 \\
Social development & .86 & $.85 * *$ & .92 \\
\hline
\end{tabular}

$* * p<.001$.

method used. The students were divided into groups according to gender (males $n=259$, females $n=224$ ), individual $(n=254)$ and team sport $(n=229)$ participation. Finally, they were divided into two more groups, according to whether they had chosen to study PE as their primary choice $(n=397)$ or as a sequential choice $(n=86)$. All students were informed about the purpose of this study, provided informed consent and it was made clear that participation was voluntary, anonymous and confidential.

\section{Current instrument validation}

We conducted a Confirmatory Factor Analysis (CFA) with the entire pooled sample in order to confirm and validate the factorial pattern suggested by Kulinna and Silverman (1999) and the appropriateness for use with Greek undergraduate students and pre-service PE teachers. Many authors agree on the importance of an a priori theory before implementing CFA (Suhr, 2006; Weston \& Gore Jr., 2006), whereas the use of exploratory factor analyses (EFA) is appropriate for new or ad hoc measures (Conway \& Huffcutt, 2003). In this study, the measurement instrument is established a priori. Consequently, it is meaningful to directly confirm its original factorial design through CFA. Furthermore, the original instrument was created with CFA and not EFA, in order not to reduce the content validity through the rejection of items, as happened in the Chinese survey (Guan et al., 2005).

CFA was performed using maximum likelihood structural equation modeling procedure, with LISREL software version 8.72 , to determine whether the preservice teacher data fit the four measurement model. Maximum likelihood procedure is the most widely method used, is used when data show multivariate normality, and, additionally, is resistant to small deviations of the data from the normal distribution (Mîndrilă, 2010; Savalei, 2008; Weston \& Gore Jr., 2006).

The general CFA models' fit is assessed by: (a) the ratio of chi-squared to degrees of freedom $\left(\chi^{2} / \mathrm{df}\right)$, with values under five indicating reasonable fit (Schumack- er \& Lomax, 2004), and (b) the Comparative Fit Index (CFI), the Non-Normed Fit Index (NNFI), the Root Mean Square Error of Approximation (RMSEA) and the Incremental Fit Index (IFI). Values below .07 for RMSEA (Steiger, 2007) and above 90 for CFI (Byrne, 1994), NNFI (Hu \& Bentler, 1999) and IFI (Widaman \& Thompson, 2003) indicate an acceptable fit. The internal consistency of the various constructs is assessed by Cronbach $\alpha$ coefficients, which need to be over .70 in order to be acceptable (Houser, 2008).

\section{Data analysis}

After the instrument's validation, the following statistical analysis was conducted using the statistical package SPSS version 17.0. Before analysis, variables were screened for accuracy of data entry, missing values, distribution (skewness and kurtosis), and potential outliers through descriptive statistics and Mahalanobis distance values. Data were analyzed using descriptive (mean, standard deviation) and inferential statistics (MANOVA). The independent variables for the three performed MANOVAs were gender, type of sport participation (individual and team sports) and choice of study in the faculty of PE (first or sequential choice). The follow-up tests were simple ANOVAs and when a statistically significant main effect was observed, the discriminant function analysis was also used. Furthermore, according to Tabachnick and Fidell (2007), a profile analysis was run in order to determine if the pre-service PE teachers considered each goal to be equally important.

\section{RESULTS}

\section{Scale reliabilities and item statistics}

In order to prepare the data for the primary analysis, they were subjected to a series of preliminary analyses (missing value analysis, assessment of normality and internal reliability analysis). Item statistics $(M, S D$, skewness and kurtosis) are added for each of the four sub-scales. According to Finney and DiStefano (2006), 
skewness and kurtosis values suggested that univariate normality is not an issue for CFA procedures, since they did not exceeded values of 2 and 7, respectively. Mahalanobis distance was $M=35.93, S D=18.25$, and no multivariate outliers were observed.

The Cronbach's $\alpha$ internal consistency instrument for the present data ranged from .75 to .81 for every single sub-scale, whereas the reliability of the overall instrument was high (.91), indicating good reliability. Compared to the values reported for the original instrument, Kulinna and Silverman's (1999) values tended to be somehow higher. A few items appeared to have low item-total correlation $(<.40)$, ranging from .33 to .67 (Table 2).

Results of the CFA demonstrated an adequate to good data fit for pre-service PE teachers $(N=483)$ to the four-domain dependent model (Table 3). Most of the standardized factor loadings resulted adequate, ranging from .25 to .60 . The majority $(35 / 36=97.2 \%)$ of the structure coefficients for the items were greater than .30. The goodness of fit indices $\left(\chi^{2} / \mathrm{df}\right.$, CFI, NNFI, RMSEA and IFI) are displayed in Table 4, with comparable data from the two previous validation studies (Kulinna \& Silverman, 1999; Kulinna et al., 2010).

\section{Descriptive and inductive statistics}

All descriptive statistics of the four sub-scales are reported in Table 4. The RM-ANOVA profile analysis, with Greenhouse-Geisser correction due to violations of sphericity $(p<.001)$, was significant, $F(3,480)=148.56, p<.001$, with a large effect size $\left(\eta^{2}=.24\right)$, suggesting that pre-service PE teachers did not view the four outcome goals as equally important. The post-hoc analysis, using the Bonferonni correction in order to control all possible comparisons, showed that physical activity and fitness was the leading outcome goal, differing statistically significantly from the three other goals $(p<.001)$. The outcome of self-actualization followed as the second most important goal, differing statistically significantly from the two remaining goals $(p<.001)$. The last two outcome goals, namely motor skill development and social development did not differ from each other $(p=.058)$.

For comparison between genders, the Box-Cox test of equality of covariance was not statistically significant at $p<.001$ (Box's $M=22.96, p=.012$ ) and the normality assumption was assumed. The MANOVA indicated that statistically significant differences were found for all four outcome goals (Hotelling's $T=.06$, $\left.F[4,478]=7.19, p<.001, \eta^{2}=.06\right)$. The MANOVA was followed up with a discriminant function analysis, which significantly differentiated males and females $\left(\Lambda=.94, \chi^{2}(4)=28.00, \quad p<.001\right)$. Females had significantly higher beliefs than males in physical activity and fitness $(F[1,481]=20.18, p<.001$, $\eta^{2}=.04$; discriminant loading $=.84$ ), self-actualization $\left(F[1,481]=21.80, p<.001, \eta^{2}=.04\right.$; discriminant loading $=.87)$, motor skill development $(F[1,481]=5.56$, $p=.02, \eta^{2}=.01$; discriminant loading $\left.=.44\right)$ and social development $\left(F[1,481]=14.73, p<.001, \eta^{2}=.03\right.$; discriminant loading $=.71)$.

For type of sport participation, the Box-Cox test was not statistically significant (Box's $M=13.56$, $p=.20$ ). The overall MANOVA did not provide any statistically significant differences (Hotelling's $T=.02$, $F[4,478]=1.75, p=.14, \eta^{2}=.01$ ), even though self-actualization goal marginally differs between the two subgroups $\left(F[1,481]=4.30, p=.04, \eta^{2}=.009\right)$. Students who participated in individual sports had higher beliefs in this goal than those who were into team sports.

Finally, no statistically significant differences were observed between the two sub-groups of students who had chosen to study in the Faculty of PE as their primary or sequential choice (Box's $M=8.72, p=.57$; Hotelling's $\left.T=.01, F[4,478]=0.958, p=.43, \eta^{2}=.008\right)$. All univariate results are presented in Table 5 .

\section{DISCUSSION}

The first research question was to assess the psychometric properties of the instrument created by Kulinna and Silverman (1999), in order to measure Greek PE prospective teachers' beliefs toward four PE curricular outcome goals. We conducted a four-factor CFA with maximum likelihood structural equation modeling procedure. All CFA's fit indices ranged from slightly lower than optimal to very good, supporting the four-factor depended model, as proposed by Kulinna and Silverman (1999). Item 24 had a moderately low factor loading $\left(.20<\left|f_{i j}\right|<.30\right)$, yet it was decided to remain in the questionnaire for four reasons: (a) to keep the original structure of the questionnaire, (b) not to reduce its content validity, (c) the CFA fit indices were very high even with the presence of this item and a final, practical reason, was that (d) of having adequate data to perform the profile analysis. An important remark to be made is that the original instrument proposed by Kulinna and Silverman (1999) had two items (no. 28 and 35) with structure coefficients lower than .30 .

Reliability and validity coefficients for the beliefs instrument showed high levels of internal consistency among items in the four domain areas of the instrument. All indices showed a similar fit with those of the original scale (Kulinna \& Silverman, 1999) and a better fit than those of the most recent research (Kulinna et al., 2010). Considering the preliminary research in the Greek population (Adamakis et al., 2012), which provided statistical evidence of the translation reliability and stability through time, the scores from the Greek instrument "Beliefs toward curricular outcome 
Table 2

Factor loadings and reliability estimates

\begin{tabular}{|c|c|c|c|}
\hline Sub-scale/item & Standardized factor loading & Item - total correlation & Cronbach $\alpha$ \\
\hline \multicolumn{4}{|c|}{ Physical activity and fitness } \\
\hline Item 1 & .42 & .51 & \\
\hline Item 8 & .32 & .35 & \\
\hline Item 11 & .46 & .55 & \\
\hline Item 13 & .56 & .61 & \\
\hline Item 18 & .43 & .49 & .80 \\
\hline Item 24 & .25 & .34 & \\
\hline Item 27 & .47 & .58 & \\
\hline Item 30 & .47 & .50 & \\
\hline Item 36 & .50 & .55 & \\
\hline \multicolumn{4}{|c|}{ Self-actualization } \\
\hline Item 4 & .43 & .50 & \\
\hline Item 7 & .50 & .54 & \\
\hline Item 10 & .48 & .52 & \\
\hline Item 16 & .48 & .48 & \\
\hline Item 17 & .41 & .41 & .75 \\
\hline Item 21 & .36 & .33 & \\
\hline Item 26 & .30 & .33 & \\
\hline Item 31 & .40 & .40 & \\
\hline Item 35 & .32 & .35 & \\
\hline \multicolumn{4}{|c|}{ Motor skill development } \\
\hline Item 3 & .51 & .54 & \\
\hline Item 5 & .50 & .53 & \\
\hline Item 12 & .59 & .61 & \\
\hline Item 14 & .58 & .67 & \\
\hline Item 19 & .44 & .48 & .81 \\
\hline Item 23 & .37 & .44 & \\
\hline Item 25 & .41 & .44 & \\
\hline Item 29 & .37 & .36 & \\
\hline Item 33 & .37 & .44 & \\
\hline \multicolumn{4}{|c|}{ Social development } \\
\hline Item 2 & .45 & .31 & \\
\hline Item 6 & .60 & .51 & \\
\hline Item 9 & .51 & .53 & \\
\hline Item 15 & .58 & .61 & \\
\hline Item 20 & .48 & .55 & .80 \\
\hline Item 22 & .32 & .31 & \\
\hline Item 28 & .41 & .49 & \\
\hline Item 32 & .49 & .50 & \\
\hline Item 34 & .35 & .42 & \\
\hline
\end{tabular}


Table 3

Goodness of fit indices with comparable data from previous studies

\begin{tabular}{lcccccc}
\hline & $\chi^{2} / \mathrm{df}$ & CFI & NNFI & IFI & RMSEA & $90 \%$ RMSEA \\
\hline Current validation & 3.27 & .93 & .93 & .93 & .069 & $.065-.072$ \\
Kulinna and Silverman (1999) & 2.03 & - & - & - & .060 & - \\
Kulinna et al. (2010) & 4.22 & .92 & - & - & .079 & $.062-.075$ \\
\hline
\end{tabular}

Table 4

Descriptive statistics by outcome goal priorities

\begin{tabular}{lccccc}
\hline & Range & $M$ & $S D$ & Minimum & Maximum \\
\hline Physical activity and fitness & $9-45$ & 37.78 & 4.30 & 22 & 45 \\
Self-actualization & $9-45$ & 35.60 & 4.19 & 23 & 45 \\
Social development & $9-45$ & 34.59 & 4.67 & 17 & 45 \\
Motor skill development & $9-45$ & 34.02 & 4.60 & 20 & 45 \\
\hline
\end{tabular}

Table 5

Descriptive statistics and differences between sub-groups

\begin{tabular}{|c|c|c|c|c|}
\hline Goals & Sub-groups & $M$ & $S D$ & $F$ \\
\hline \multirow[t]{6}{*}{ Physical activity/fitness } & Male & 36.98 & 4.50 & $20.16 * *$ \\
\hline & Female & 38.71 & 3.86 & \\
\hline & Individual sport & 38.14 & 4.14 & 3.76 \\
\hline & Team sport & 37.38 & 4.45 & \\
\hline & Primary choice & 37.93 & 4.17 & 2.76 \\
\hline & Sequential choice & 37.08 & 4.82 & \\
\hline \multirow[t]{6}{*}{ Self-actualization } & Male & 34.79 & 4.03 & $21.80^{* *}$ \\
\hline & Female & 36.54 & 4.19 & \\
\hline & Individual sport & 35.97 & 4.06 & $4.30^{*}$ \\
\hline & Team sport & 35.18 & 4.30 & \\
\hline & Primary choice & 35.65 & 4.16 & 0.34 \\
\hline & Sequential choice & 35.36 & 4.35 & \\
\hline \multirow[t]{6}{*}{ Motor skill development } & Male & 33.56 & 4.66 & $5.56^{*}$ \\
\hline & Female & 34.55 & 4.48 & \\
\hline & Individual sport & 34.09 & 4.60 & 0.14 \\
\hline & Team sport & 33.94 & 4.62 & \\
\hline & Primary choice & 34.16 & 4.58 & 2.16 \\
\hline & Sequential choice & 33.36 & 4.69 & \\
\hline \multirow[t]{6}{*}{ Social development } & Male & 33.84 & 4.74 & $14.73^{* *}$ \\
\hline & Female & 35.46 & 4.45 & \\
\hline & Individual sport & 34.90 & 4.45 & 2.33 \\
\hline & Team sport & 34.25 & 4.90 & \\
\hline & Primary choice & 34.67 & 4.72 & 0.65 \\
\hline & Sequential choice & 34.22 & 4.45 & \\
\hline
\end{tabular}

Note. Box's Test for: (1) gender: Box's $M=22.96, p=.012$; (2) sport: Box's $M=13.56, p=.20$; (3) choice: Box's $M=8.72, p=.57$. $* p<.05,{ }^{* *} p<.001$. 
goals" can be considered a valid and reliable. This is an important issue, because only instruments with acceptable validity and reliability can be used to collect data to enrich or generate new knowledge.

PE students identified the physical activity leading to fitness goal as the most important one, followed by self-actualization, social development and motor skill development. Although they held strong beliefs for all domains, statistically significant differences were observed, suggesting that they did not consider them to be equally important. Tinning (2010) has argued that "there is no Holy Grail of PE pedagogies" (p. 64). For this reason it is of great importance for PE students and in-service PE teachers to know their priority educational goal. Only then they will be able to achieve it, by implementing suitable educational methods and strategies, keeping always in mind the values and specific demands of the social context they live in.

Our findings are similar to Kulinna and Silverman's (2000) and Kulinna et al. (2010), especially in the two priority goals. All students' sub-groups rated these outcomes in a similar way. This reveals that all students, despite their background, think in a similar way about PE's outcomes and their previous experiences do not differentiate the outcomes' classification. No differences were observed between students whose priority was to study PE and sport science and those who entered the Faculty of PE by chance or because they failed to study in their primary Faculty's choice. Therefore it is logical to assume that the will to become a PE teacher, or not, does not differentiate the beliefs toward curricular outcome goals, since these two categories have similar ones.

Differences were found when beliefs according to gender were examined. Most of the previous researches (Guan et al., 2005; Kulinna \& Silverman, 2000; Placek et al., 1995) resulted in an opposite conclusion. Just one (Alshammari, 2004) observed statistically significant differences between males' and females' beliefs, which were attributed to the nature of culture and education in Kuwait. However, in the Greek study, this may be partially correct. The classification pattern did not change, but female students evaluated all four outcome goals higher than males, possibly because beliefs are socially constructed representational systems (Rust, 1994). This means that female students in the Faculty of PE and Sport Science of Athens University are socialized to more easily accept and perform emotional and expressive roles, while men believe they should have more active ones (Mooney, Knox, \& Schacht, 2009). So, socially constructed gender roles, through which students adopt socially acceptable behaviors, seem to be stronger than other western countries, even today.
The first remark is that motor skill development was placed last in students' beliefs. This goal was the dominant one in the 90's (Placek et al., 1995) and today it is still considered important in the elementary education (Matanin \& Kollier, 2003), but seems to be outdated. The major concern is that the Greek PE curriculum is focused on motor skill development (M. E. R. A., 2003), but this is not reflected in teacher education students' beliefs, since they think this is the last goal, out of four, to be pursued. It seems that they do not accept the prioritization as proposed and adopted by the Greek state on the desired outcomes of school PE. So the official curriculum is not justified by them, since it does not reflect their beliefs, even though they have experienced this specific curriculum as school pupils and through apprenticeship of observation.

This discrepancy between students' beliefs and the national policy texts is not just a national issue, since it has been proposed by Meek and Curtner-Smith (2004) in the past. MacLean, Mulholland, Gray, and Horrell (2013) have also noticed that there is a lack of communication between national-level policy constructors and the local-level teachers, transferring this curriculum inconsistency into practice and not just in a theoretical level. However in Greece, and especially in secondary education, motor skill development is mainly about learning sport skills and sport techniques. It has a narrow focus on physical skill acquisition, which usually does not include the affective and cognitive domains (Drewe, 2000). These skills are related just to a limited number of sports and no attempt is made to link them with other areas of human movement and activity. A "motor elitism" seems to exist, where skillful performance is a valued commodity, but only high ability students are entitled to quality instructional programs (Bain, 1990). According to our point of view, this process has turned into a mechanical routine of motor skills learning and individual's technique development. These are taught by a unique and, often, stereotyped way which is associated just with three or four sports (mainly football, basketball, volleyball and handball here in Greece). So the end result is these specific sports, regardless as to whether these are useful skills for human movement as a whole, for their use in everyday life and for the promotion of lifelong physical activity.

Third to be evaluated, not differing statistically significantly from the previous goal was social development. In all previous investigations, this goal was somehow neglected (Guan et al., 2005; Kulinna et al., 2010; Kulinna \& Silverman, 2000; Xiang et al., 2002). The Greek curriculum sets as one of the primary goals for PE the children's harmonious integration in society (M.E.R.A., 2003). However this purpose is vaguely worded and no clear guidance exists on how it should 
be achieved. So no strong beliefs toward social development can be created if there are not clearly defined objectives, through specific intervention programs, such as cooperative learning (e.g. Bayraktar, 2011; Goudas \& Magotsiou, 2009) and teamwork development (e.g. Bailey et al., 2009). In order to enhance social development, cooperation and diversity acceptance, an important prerequisite is the revival of competition $($ com-petitio $=$ to strive together $)$ and the elimination of antagonism. As Drewe (2000) has noticed, "this striving together necessitates a respect for opponents, since too often competitors lose sight of striving together to improve their skills and their desire to win results in disrespectful actions" (p. 85). We are not sure that this can be done in the neoliberal society we live in.

Even the students who participated in team sport activities did not evaluate the social development outcome goal higher, compared to the ones who were involved in individual sports. On the other hand, the latter evaluated the self-actualization goal marginally higher than the previous ones. These results give us a hint that even if team sports provide the appropriate emphasis on collaboration, on cooperative learning and acceptance of diversity, this is limited exclusively within the context of the "team" and no connection is being made with the rest of the students' social activity. While, on the other hand, students who participated in individual sports had higher beliefs regarding selfactualization probably because the goals and the objectives of these kinds of sports depend on the individual performance of the participants.

The self-actualization outcome goal was evaluated high enough, resulting second, behind the physical activity and fitness goal. In just one previous research (Guan et al., 2005) this goal was the primary one. Usually it is considered to be the second in order (Kulinna et al., 2010; Kulinna \& Silvermanm 2000; Wang \& Koh, 2006). This is a positive result because self-actualization, according to Maslow's theory (1979), is considered the ultimate human goal. In our research, this goal focuses on developing self-esteem, self-confidence, enjoyment and self-efficacy. If PE needs to be considered a sub-category of individuals' general education, leading to a holistic and harmonious human, and not just bodily development, an education for intellectual and emotional independence as the famous German sociologist H. Markuze (1965) has noticed, this outcome goal should be considered an important one. PE's effects on physical activity and fitness levels are well known. However, other types of positive effects, such as effects on cognitive performance (i.g. Etnier, Nowell, Landers, \& Sibley, 2006) which can contribute to the holistic human development, are marginalized. Holding this position the Cartesian mind-body dualism that exists even today can be overcome. So PE teachers should try to recreate the purpose of PE, transforming it from "education of the physical" to "education through the physical" and reinforce their beliefs toward self-actualization. We do not believe that this "theoretical redefinition, no matter how justified, must remain academic since as it goes against the predominant trend" (Markuze, 1965, p. 198) a trend which in our case is the physical activity for health improvement. This redefinition could be achieved by connecting biological sciences (i.e. biomechanics, ergo-physiology) to humanistic sciences (i.e. sport pedagogy, sociology, psychology), in favor of a holistic approach to human individuality and not just a bodily one. Kahne (1996) also suggests the promotion of personal development in a unified and systematic way, rather than promoting isolated educational goals, such as self-esteem and critical thinking.

In this study, students held the strongest beliefs toward the physical activity, leading to fitness and improved health, goal. This was somehow expected, since most recent research has come to the same conclusion (Kulinna et al., 2010; Kulinna \& Silverman, 2000; Wang \& Koh, 2006; Xiang et al., 2002). In our time this goal is the primary one due to the worldwide "obesity crisis" and the high overweight rates. As we argued before, the bodily impacts of physical activity are well known and widely discussed in the international literature. Physically active children have less body fat, decreased risk for cardiovascular diseases and diabetes, lower rates of stress and depression and better health (Welk et al., 2006). So school, through PE classes, can become the center of primary intervention for improving children's health, through increased physical activity and fitness. In order for this goal to be feasible, PE should not base on traditional practices of teaching motor skills and sports (Sallis et al., 1999). Furthermore it should not be based on antagonism and victory, and should emphasize children's developmental skills, such as self-determination and self-motivation, while providing them with the intellectual capacity to choose for themselves to be physically active (Dale, Corbin, \& Cuddihy, 1998; MacNamara et al., 2011).

The clear discrepancy regarding the main purpose of school PE is obvious between policy constructors and PE teachers. MacLean et al. (2013) have stated that given the strength of the health discourse in modern societies, teachers may interpret the policy texts exclusively in relation to improving health, fitness and increase students' physical activity levels. So there is evidence in our study that PE teachers understand the primary PE purpose as the improvement of children's fitness, distorting the intensions of policy constructors.

These days, when sedentary and screen-based inactivity has been adopted by the majority of the western societies, school PE cannot be the only activity respon- 
sible for promoting children's activity and health. In order for this objective to be achieved, wider social and environmental changes are needed and, of course, a clearly communicated vision for school PE. The underfunding and the lack of social support limits even further this role (Welk et al., 2006). Furthermore, the time devoted to PE in the school setting is insufficient and constantly decreasing. The students' participation in one to three hours per week in PE classes, which is the most common practice, makes it difficult to improve their physical fitness and health (Ericsson, 2011). Physical activity leading to fitness may be the most valuable instrument in $\mathrm{PE}$, but it cannot be an end in itself. It may be considered, in a worldwide basis, the primary outcome goal for PE, it may have the potential to differentiate PE classes' outcomes from other subject matters and it can contribute to students' health. However, health's improvement may be a feasible goal only if we take into account the "energy intake, energy consumption" reductionist logic, failing to take into consideration the complicated discourses between physical activity, fitness and health. PE teachers must begin to educate children about these problematic relationships.

\section{CONCLUSION}

The purpose of this study was to validate the scores of Kulinna and Silverman's (1999) instrument for measuring students' beliefs toward curricular outcomes in the Greek setting. These scores of the Greek version of the "Beliefs toward curricular outcome goals" instrument have been demonstrated valid and reliable. Further research is needed with different samples in order to stabilize its validity in the Greek context.

Another aim of the research was to examine how PE students classify the four important PE outcome goals and whether differences between sub-groups existed. The primary goal of the Greek curriculum, which is motor skill development, is considered the least important according to PE students' beliefs. Only gender differences were observed, possibly because females are socialized to more easily accept and perform emotional and expressive roles, since beliefs are socially constructed representational systems. Team sports did not help individuals to create higher beliefs for the social development goal, while students who participated in individual sport activities had higher beliefs toward self-actualization. In general, beliefs toward curricular outcomes were classified as follows: (1) physical activity and fitness, (2) self-actualization, (3) social development, (4) motor skill development.

This classification seems obvious given the negative changes in young Greeks' health and the high overweight rates. Enhanced fitness through school PE may lead to the amelioration of students' health. However it is argued that school PE alone cannot achieve this goal. Physical activity could be a very precious instrument for PE, which would lead to health, holistic human development and, finally to individuals' self-actualization, and also the element that differentiates PE from other school lessons. In this way, PE would become the "education through the physical" and not just the "education of the physical" as it is today. This transition would help professors see students as holistic entities and not divided into body and mind, who just need their bodies to be kept fit and educated.

Future research should be directed toward a more complete examination of PE students' and teachers' belief systems. It is of major importance to understand how these are created, what influences them and the way they are developed during the occupational socialization process. Finally, we should examine the way beliefs are related to the actual everyday behavior and actions of PE teachers.

\section{ACKNOWLEDGMENT}

In memory of prof. Dimitris Hatziharistos, a dear friend and an excellent supervisor.

\section{REFERENCES}

Adamakis, M., Stavrou, N. A., Georgadis, E. M., \& Yannakoulia, M. (2014). John: A coordinated approach to developing an active lifestyle. In $\mathrm{K}$. Armour (Ed.), Pedagogical Cases in Physical Education and Youth Sport (pp. 235-246). Oxford: Routledge.

Adamakis, M., Zounhia, K., Hatziharistos, D., \& Psychountaki, M. (2012). Prokatarktiki meleti engirotitas kai axiopistias tis klimakas "Pepithisis gia tus skopus tis Fisikis Agogis" [Preliminary study on validity and reliability control of the "Beliefs toward curriculum in Physical Education" scale]. Kinesiology (Special Issue), 5, 8-9.

Alshammari, O. (2004). Teachers' perceptions of the goals of secondary schools Physical Education in state of Kuwait. Doctoral dissertation in Curriculum and Instruction, Department of Curriculum and Instruction, University of West Virginia, Morgantown. Retrieved from the ProQuest Multiple databases: http://www.researchgate. net/publication/35711942_Teachers\%27_ perceptions_of_the_goals_of_secondary_ schools_physical_education_in_state_of_Kuwait_ electronic_resource

Bailey, R., Armour, K., Kirk, D., Jess, M., Pickup, I., \& Sandford, R. (2009). The educational benefits claimed for physical education and school sport: 
An academic review. Research Papers in Education, 24(1), 1-27.

Bain, L. L. (1990). A critical analysis of the hidden curriculum in Physical Education. In D. Kirk \& R. Tining (Eds.), Physical Education, curriculum and culture: Critical issues in the contemporary crisis (pp. 19-34). Hampshire: The Falmer Press.

Bayraktar, G. (2011). The effect of cooperative learning on students' approach to general gymnastics course and academic achievements. Educational Research and Reviews, 6, 62-71.

Burrows, L., Wright, J., \& Jungersen-Smith, J. (2002). Measure your belly: New Zealand children's constructions of health and fitness. Journal of Teaching in Physical Education, 22, 39-48.

Byrne, B. M. (1994). Structural equation models with EQS and EQS/Windows. London, UK: SAGE.

Colquhoun, D. (1990). Images of healthism in healthbased Physical Education. In D. Kirk \& R. Tining (Eds.), Physical Education, curriculum and culture: Critical issues in the contemporary crisis (pp. 39-58). Hampshire: The Falmer Press.

Conway, J. M., \& Huffcutt, A. I. (2003). A review and evaluation of exploratory factor analysis practices in organizational research. Organizational Research Methods, 6, 47-168.

Curtner-Smith, M. D. (1999). The more things change the more they stay the same: Factors influencing teachers' interpretations and delivery of national curriculum physical education. Sport, Education and Society, 4, 75-97.

Curtner-Smith, M. D., Hastie, P. A., \& Kinchin, G. D. (2008). Influence of occupational socialization on beginning teachers' interpretation and delivery of sport education. Sport, Education and Society, 13, 97-113.

Dale, D., Corbin, C. B., \& Cuddihy, T. E. (1998). Can conceptual physical education promote physically active lifestyles? Pediatric Exercise Science, 10, 97109.

Doolittle, S. A., Dodds, P., \& Placek, J. H. (1993). Persistence of beliefs about teaching during formal training of preservice teachers. Journal of Teaching in Physical Education, 12, 355-365.

Drewe, S. B. (2000). An examination of the relationship between coaching and teaching. Quest, 52, 79-88.

Ennis, C. D. (1994). Knowledge and beliefs underlying curricular expertise. Quest, 46, 164-175.

Ennis, C. D. (1996). A model describing the influence of values and context on student learning. In S. J. Silverman \& C. D. Ennis (Eds.), Student learning in Physical Education (pp. 127-147). Champaign, IL: Human Kinetics.
Ericsson, I. (2011). Effects of increased physical activity on motor skills and marks in physical education: An intervention study in school 1 through 9 in Sweden. Physical Education and Sport Pedagogy, 16, 313-329.

Etnier, J. L., Nowell, P. M., Landers, D. M., \& Sibley, B. A. (2006). A meta-regression to examine the relationship between aerobic fitness and cognitive performance. Brain Research Reviews, 52, 119-130.

Finney, S. J., \& DiStefano, C. (2006). Nonnormal and categorical data in structural equation modeling. In G. R. Hancock \& R. O. Mueller (Eds.), Structural equation modeling: A second course (pp. 269-314). Greenwich, CT: Information Age Publishing.

Goldin, G. A. (2002). Affect, meta-affect, and mathematical belief structures. In G. Leder, E. Pehkonen, \& G. Törner (Eds.), Beliefs: A hidden variable in mathematics education? (pp. 59-72). Dordrecht: Kluwer.

Goudas, M., \& Magotsiou, E. (2009). The effects of a cooperative physical education program on students' social skills. Journal of Applied Sport Psychology, 21, 356-364.

Graber, K. C. (1995). The influence of teacher education programs on the beliefs of student teachers: General pedagogical knowledge, pedagogical content knowledge, and teacher education course work. Journal of Teaching in Physical Education, 14, 157-178.

Graber, K. C. (1996). Influencing student beliefs: The design of a "high impact" teacher education program. Teaching and Teacher Education, 12, 451-466.

Guan, J., McBride, R., \& Xiang, P. (2005). Chinese teachers' attitudes toward teaching physical activity and fitness. Asia-Pacific Journal of Teacher Education, 33, 147-157.

Hatziharistos, D. (2003). Sinkhrono sistima Fisikis Agogis: Apo tin theoria stin praxi [Modern system of Physical Education: From theory to practice]. Athens: Hatziharistos.

Houser, J. (2008). Precision, reliability, and validity: Essential elements of measurement in nursing research. Journal for Specialists in Pediatric Nursing, 13, 297-299.

Hu, L., \& Bentler, P. M. (1999). Cut off criteria for fit indexes in covariance structure analysis: Conventional criteria versus new alternatives. Structural Equation Modeling, 6, 1-55.

Kahne, J. (1996). Reframing educational policy: Democracy, community, and the individual. New York, NY: Teachers College Press.

Kirk, D. (1993). Curriculum work in physical education: Beyond the objectives approach? Journal of Teaching in Physical Education, 12, 244-265. 
Kulinna, P. H., Brusseau, T., Ferry, M., \& Cothran, D. (2010). Preservice teachers' belief systems towards curricular outcomes for Physical Education. Research Quarterly for Exercise and Sport, 81, 189-198.

Kulinna, P. H., \& Silverman, S. (1999). The development and validation of scores on a measure of teachers' attitudes toward teaching physical activity and fitness. Educational and Psychological Measurement, 59, 507-517.

Kulinna, P. H., \& Silverman, S. (2000). Teachers' attitudes toward teaching physical activity and fitness. Research Quarterly for Exercise and Sport, 71, 80-84.

Lara-Cinisomo, S., Fuligni, A. S., Ritchie, S., Howes, C., \& Karoly, L. (2008). Getting ready for school: An examination of early childhood educators' belief system. Early Childhood Educational Journal, 35, 343-349.

MacLean, J., Mulholland, R., Gray, S., \& Horrell, A. (2013). Enabling curriculum change in physical education: The interplay between policy constructors and practitioners. Physical Education and Sport Pedagogy.

MacNamara, A., Collins, D., Bailey, R., Toms, M., Ford, P., \& Pearce, G. (2011). Promoting lifelong physical activity and high level performance: Realizing an achievable aim for physical education. Physical Education and Sport Pedagogy, 16, 265-278.

Markuze, H. (1965). Remarks on a redefinition of culture. Daedalus, 94(1), 190-207.

Maslow, A. H. (1979). Toward a psychology of being (2nd ed.). New York, NY: D. Van Nostrand Co.

Matanin, M., \& Collier, C. (2003). Longitudinal analysis of preservice teachers' beliefs about teaching Physical Education. Journal of Teaching in Physical Education, 22, 153-168.

Meek, G., \& Cutner-Smith, M. D. (2004). Preservice teachers' value orientations and their compatibility with the national curriculum for Physical Education. The Physical Educator, 61, 88-101.

Mîndrilă, D. (2010). Maximum likelihood (ML) and diagonally weighted least squares (DWLS) estimation procedures: A comparison of estimation bias with ordinal and multivariate non-normal data. International Journal of Digital Society, 1(1), 60-66.

Ministry of Education and Religious Affairs (M. E. R. A.) (2003). Diathematiko enieo plesio programmatos spudon Fisikis Agogis [Interdisciplinary curriculum framework in Physical Education]. Athens: M. E. R. A. Retrieved from http://www.pi-schools.gr/programs/depps/
Mooney, L. A., Knox, D., \& Schacht, C. (2009). Understanding social problems (6th ed.). Belmont, CA: Wadsworth, Cengage Learning.

Nash, R. (2003). Inequality/difference in New Zealand education: Social reproduction and the cognitive habitus. International Studies in Sociology of Education, 13, 171-191.

Pajares, F. (1992). Teachers' beliefs and educational research: Cleaning up a messy construct. Review of Educational Research, 62, 307-332.

Pate, R. P., Davis, M. G., Robinson, T. N., Stone, E. J., McKenzie, T. L., \& Young, J. C. (2006). Promoting physical activity in children and youth: A leadership role for schools - a scientific statement from the American Heart Association Council on Nutrition, Physical Activity, and Metabolism (Physical Activity Committee) in collaboration with the councils on cardiovascular disease in the young and cardiovascular nursing. Circulation, 114, 1214-1224.

Placek, J. H., Dodds, P., Doolittle, S. A., Portman, P. A., Ratliffe, T., \& Pinkham, K. M. (1995). Teaching recruits' physical education backgrounds and beliefs about purposes for their subject matter. Journal of Teaching in Physical Education, 14, 246-261.

Roditis, M. L., Parlapani, E. S., Tzotzas, T., Hassapidou, M., \& Krassas, G. E. (2009). Epidemiology and predisposing factors of obesity in Greece: From the second world war until today. Journal of Pediatric Endocrinology \& Metabolism, 22, 389-405.

Rust, F. (1994). The first year of teaching: It's not what they expected. Teaching and Teacher Education, 10, 205-217.

Sallis, J. F., McKenzie, B., Kolody, M., Lewis, M., Marshall, S., \& Roengard, P. (1999). Effects of health-related physical education on academic achievement: Project SPARK. Research Quarterly for Exercise and Sport, 70, 127-134.

Savalei, V. (2008). Is the ML chi-square ever robust to nonnormality? A cautionary note with missing data. Structural Equation Modeling, 15, 1-22.

Schumacker, R. E., \& Lomax, R. G. (2004). A beginner's guide to structural equation modeling (2nd ed.). Mahwah, NJ: Lawrence Erlbaum Associates, Inc.

Steiger, J. H. (2007). Understanding the limitations of global fit assessment in structural equation modeling. Personality and Individual Differences, 42, 893-898.

Suhr, D. D. (2006). Exploratory of confirmatory or exploratory factor analysis? In SUGI 31 Proceedings. Cary, NC: SAS Institute Inc. Retrieved from http://www2.sas.com/proceedings/sugi31/200-31. pdf 
Tabachnick, B. G., \& Fidell, L. S. (2007). Using multivariate statistics (5th ed.). Boston, MA: Allyn \& Bacon.

Tambalis, K. D., Panagiotakos, D. B., Kavouras, S. A., Kallistratos, A. A., Moraiti, I. P., Douvis, S. J., Toutouzas, P. K., \& Sidossis, L. S. (2009). Eleven-year prevalence trends of obesity in Greek children: First evidence that prevalence of obesity is leveling off. Obesity, 18, 161-166.

Tinning, R. (1990). Ideology and Physical Education. Victoria, Australia: Deakin University Press.

Tinning, R. (2010). Pedagogy and human movement. Theory, practice, research. Oxon, OX: Routledge.

Tsangaridou, N. (2006). Teachers' beliefs. In D. Kirk, D. Macdonald, \& M. O'Sullivan (Eds.), The Handbook of Physical Education (pp. 486-501). London: SAGE.

Tsangaridou, N. (2008). Trainee primary teachers' beliefs and practices about physical education during student teaching. Physical Education and Sport Pedagogy, 13, 131-152.

Wang, C. J., \& Koh, T. M. (2006). Sport ability beliefs, achievement goals, self-determination and beliefs about the purposes of Physical Education among Singaporean preservice physical education trainees. Asian Journal of Exercise and Sports Science, 3(1), 25-34.

Welk, G. J., Eisenmann, J. C., \& Dollman, J. (2006). Health-related physical activity in children and adolescents: A bio-behavioral perspective. In D. Kirk, D. Macdonald, \& M. O'Sullivan (Eds.), The handbook of Physical Education (pp. 665-684). London: SAGE.

Welk, G. J., \& Meredith, M. D. (Eds.). (2008). Fitnessgram/Activitygram: Reference guide. Dallas, TX: The Cooper Institute.

Weston, R., \& Gore Jr., P. A. (2006). A brief guide to structural equation modeling. The Counseling Psychologist, 34, 719-751.

Widaman, K. F., \& Thompson, J. S. (2003). On specifying the null model for incremental fit indices in structural equation modeling. Psychological Methods, 8, 16-37.

Xiang, P., Lowy, S., \& McBride, R. (2002). The impact of a field-based elementary physical education methods course on pre-service classroom teachers' beliefs. Journal of Teaching in Physical Education, $21,145-161$.

Zounhia, K. (2000). Fisiki Agogi sto Dimotiko skholio: Pros ti dia viu aksisi [Physical Education in primary school: Toward life-long physical activity]. Athens: Zounhia.

Zounhia, K. (2009). Preservice physical education teacher education: A research review. Inquiries in Sport \& Physical Education, 7, 130-148.

\section{NÁZORY ŘECKÝCH STUDENTU゚ UČITELSKÉHO OBORU TĚLESNÁ VÝCHOVA NA ORIENTACI STUDIJNIICH PLÁNŮ: VALIDACE NÁSTROJE A OVĚŘENÍ ČTYŘ VÝZNAMNÝCH CÍLŮ}

(Souhrn anglického textu)

ÚVOD: Způsob, jakým lidé vnímají realitu, je ovlivněn jejich duševními konstrukcemi, kognitivními schopnostmi a přesvědčením. Studenti tělesné výchovy (TV) mají široký okruh názorů týkajících se účelu TV, jež je nesnadné změnit, a to ani během vysokoškolského studia.

CÍL: Tato studie ověřila výsledky z předchozího dotazníku a prošetřila názorový systém studentů tělesné výchovy vzhledem $\mathrm{k}$ cílům uvedeným $\mathrm{v}$ řeckých učebních plánech.

METODY: Studenti $(N=483$; muži $=259$, ženy $=224)$ z řecké Fakulty tělesné a sportovní výchovy vyjádřili své názory na výsledky učebních plánů. Vyplnili řeckou verzi nástroje závislého na čtyřech faktorech „Názory na učební plán v tělesné výchově“. Validace nástroje byla provedena pomocí konfirmační faktorové analýzy, po níž následovala vícerozměrná analýza rozptylu (MANOVA) rozdílů v rámci skupiny. Nakonec proběhla profilová analýza zjištující, zda studenti TV považovali každý cíl za stejně významný.

VÝSLEDKY: Validace nástroje potvrdila navrhovaný model závislý na čtyřech faktorech. Vnitřní soudržnost i konfirmační faktorová analýza odpovídaly ukazatelům a dodaly validní a spolehlivé výsledky. Závažná byla profilová analýza, jež naznačila, že studenti nepovažovali cíle za stejně důležité. Hlavním cílem byla fyzická aktivita a tělesná kondice (fitness), následovala seberealizace, sociální vývoj a vývoj motorických dovedností. Výsledky MANOVA, srovnávající jednotlivé podskupiny, ukázaly významnější rozdíly pouze mezi pohlavími.

ZÁVĚRY: Řečtí studenti tělesné výchovy v současnosti považují za nejvýznamnější cíl fyzickou aktivitu a tělesnou kondici, zatímco vývoj motorických dovedností považují za ten nejméně důležitý.

Klícová slova: studenti, tělesná kondice, seberealizace, motorické dovednosti, sociální vývoj, dotazník, validita, spolehlivost, CFA. 